\title{
ACCESSIBILITY OF DISCOURSAL DATA IN CRITICAL GENRE ANALYSIS: INTERNATIONAL COMMERCIAL ARBITRATION PRACTICE*
}

\author{
Vijay K. Bhatia**
}

Abstract: Critical genre analysis, especially targeting specific professional practices, crucially depends on the availability of discursive data from the professional practice under investigation, which is not always easily accessible. In this paper, I take up a typical example of this kind of difficulty focusing on an international initiative, in which I have been involved for the last several years, with collaboration from more than twenty research teams from as many countries. By drawing on discoursal data (narrative, documentary and interactional), it is possible to look at the motivations for interdiscursive processes and procedures. However, the so-called duty to strict confidentiality observed and practiced in international arbitration practice makes it difficult to get access to data from arbitration practice and thus to undertake such critical genre-based interdisciplinary research. In this paper, I will focus on some of the important issues involved in this study of professional practice and discuss implications of this generally assumed requirement of confidentiality, and its implications for research in and development of the institution of arbitration. I also propose alternatives to collection of data from arbitration practice to make such research possible.

Keywords: Critical genre analysis. Professional practices. Arbitration practices.

\section{INTRODUCTION}

In this paper, I would like to discuss the issue of inaccessibility of discursive data for critical genre analytical studies of professional, institutional or other organizational practices. Drawing on the investigation of the increasing interdiscursive influence of litigation on arbitration practices in international commercial contexts, I would also like to distinguish critical genre analysis of professional practices (Bhatia, 2008b) from traditional genre analyses of textual genres (Swales, 1990,

\footnotetext{
* The work reported here draws on an RGC CERG grant from The Government of Hong Kong (Project No. CityU1051/06H) International Arbitration Practice: A Discourse Analytical Study. Website: http://enweb.cityu.edu.hk/arbitrationpractice.

** City University of Hong Kong, Hong Kong. Email: enbhatia@cityu.edu.hk.
} 
Bhatia, 1993). The study offers a number of interesting challenges to genre theory, which can be employed in the investigation of professional, institutional and other workplace-related corporate practices. It tends to offer a useful procedure for the study of professional practices, which otherwise are often discussed and explained through organizational, management, and other institutional theories (BOJE et al. 2004; HARDY et al., 2004; MARSHAK et al., 2000; PHILLIPS et al., 2002; GRANT et al., 2001; OSWICK; GRANT, 1997). Critical genre theory offers a complementary methodological alternative in the form of a discoursebased investigation of a range of professional, organizational and institutional practices. At a more theoretical level, it creates a valuable research context for the development of a more comprehensive and delicate system of interdiscursivity in genre theory (BHATIA, 2010), which has not been sufficiently explored in the current literature on genre. More generally, it underpins the importance of a multidimensional and multi-perspective view of genre analysis, which, in my view, has tremendous potential for the future of genre studies.

I would like to illustrate this phenomenon by taking up the case of interdiscursive colonization of international commercial arbitration practice by drawing on the interdiscursive analyses of a range of discoursal data drawn from international commercial arbitration practice using a multidimensional and multi-perspective genre analytical framework (BHATIA, 2004). The data required for this kind of study includes critical moments of interaction from specific crucial sites of arbitration practice, narratives of experience drawn from interviews with key practitioners, court judgments and arbitration awards, and from professional commentaries on arbitration concepts and practices. These diverse sources of data and their analyses can then be integrated into a 'thick description' (GEERTZ, 1973) of the concept of arbitration, it's role, concerns, practices, as well as tensions on the part of participants, who come from a range of disciplinary and jurisdictional backgrounds, and sites. Since, the main focus of this research is on the investigation of the increasing influence of litigative procedures on arbitration practice, and resistance to such an encroachment, it requires a rich and interdiscursive account of the contested discourses grounded in a range of sites and drawing on a plurality of data sets. However, before going any further, it 
is necessary to give a brief account of international commercial arbitration practice.

\section{INTERNATIONAL COMMERCIAL ARBITRATION PRACTICE}

Arbitration was originally proposed as an alternative to litigation in order to provide a flexible, economic, speedy, informal, and private and confidential process of resolving commercial disputes. Mutual agreement between the parties in dispute was recommended as a necessary pre-requisite for any arbitration proceeding. At the same time, parties were given considerable freedom to choose procedures, including the choice of arbitrator as well as the seat of arbitration. There was a duty of implied confidentiality in that the arbitration documents, whether spoken or written, presented, discussed, or produced were to be protected from disclosure to outsiders to the dispute and the proceedings were generally to take place in private. The biggest selling point of international commercial arbitration has been that arbitration awards are enforceable internationally.

Although arbitration awards are final and enforceable, parties at dispute often look for opportunities to go to the court when the outcome is not to their liking, sometimes for good reasons. They often choose legal experts as arbitrators and as counsels, as they are likely to be more accomplished in looking for opportunities to challenge a particular award. In order to exercise the autonomy of the parties, sometimes chosen rules are closer to complex court proceedings than they are to the simpler rules of arbitration. Such variation naturally leads to an increasing mixture of rule-related discourses as arbitration becomes, as it were, 'colonized' by litigation practices, threatening to undermine the integrity of arbitration practice, and in the process thus compromising the spirit of arbitration as a non-legal practice. Nariman (2000), one of the distinguished international scholars in International Commercial Arbitration, points out, "International Commercial Arbitration has become almost indistinguishable from litigation, which it was at one time intended to supplant". However, there is very little research evidence to support such statements from experts in the field, including some from 
members of the legal community. Hence there is a need to undertake an evidence-based investigation into this aspect of professional practice.

One such effort is the international project funded by the Research Grants Council HKSAR under Competitive Earmarked Research Grant, entitled International commercial arbitration practice: a discourse analytical study in collaboration with more than twenty international teams of researchers, drawn both from legal and arbitration practice, as well as from discourse analysis. One of the key objectives in the project is to investigate the 'integrity' of the current international arbitration practice by analyzing various sets of complementary textual, narrative, and discursive data. In order to achieve these objectives, we use a multiperspective and multidimensional genre analytical framework (BHATIA, 2004) to integrate analyses of data collected from at least three different sources:

a) Intertextual and interdiscursive relationships among discursive practices in arbitration;

b) Narratives of experience of key practitioners tested against other stakeholders;

c) Analyses of critical moments in the discourses of arbitration practice.

Such a critically reflexive approach is characterized by an integration of mixed methodologies (CANDLIN; SARANGI, 2001, 2004), textual, narratological and discursive, as well as both quantitative and qualitative. It is true that arbitration and litigation practices are never so clear-cut; their boundaries are frequently blurred, at least for the outsiders, if not for the practitioners themselves. However, it is possible to take advantage of such blurring by reflexively seeking confirmations of the communicative characteristics of arbitration process by testing practitioner hypotheses against other practitioners' experiences and against the actualities of interaction in 'critical sites of engagement' (SCOLLON, 2001), especially at 'critical moments' of interaction. We realize that in order to be rigorous in our investigation, we require not only access to actual data from practice, but also an engagement of the professional community in research collaboration. It is with this point of view that the project has sought involvement of the members of the arbitration community. 


\section{CONFIDENTIALITY AND NON-ACCESSIBILITY OF DATA}

The duty of confidentiality and privacy in arbitration practices and procedures, the presumed strength and one of the so-called 'selling points' of international commercial arbitration practice, seems to have become a major stumbling block for the study of arbitration as an alternative to litigation in international commercial contexts. We have discovered that there is very limited access to the discourses of and in arbitration. So far as the written arbitration discourse is concerned, the most important genre in international contexts is what is known as arbitration awards, which are the equivalent of court judgements in litigation. There are some awards accessible in the form of sanitised extracts published by international agencies such as the International Chamber of Commerce (International Court of Arbitration). However, these awards are few and far between. So far as the spoken data is concerned, the most important data required is from the actual arbitration practice (trial), which is almost certainly inaccessible to outsiders because of the general duty of privacy and confidentiality, which is taken as a necessary pre-requisite to an arbitration trial. However, the critical question is whether it is really the case, or is it that this requirement of confidentiality is only used as an excuse to preserve the business interests of some of the key players in the community of practice. In this context, I would like argue for a more relaxed confidentiality requirement, particularly for the advancement of research and development of the institution of international arbitration in the coming years. Views and concerns about the necessity of taking privacy and confidentiality as a given requirement for international commercial arbitration practice are interesting, and have attracted diverse reactions, both in favour of and against, its protection from disclosure for different purposes and under different sets of conditions. I would like to discuss some of these perceptions here.

There seems to be a general agreement among legal scholars, judges, and arbitration practitioners that there is a duty of confidentiality to be observed which implies that parties in dispute shall not disclose any information in and about the arbitration process, including the award, to any third parties not involved in the process. This general expectation of 
confidentiality of arbitral proceedings may be absolute in some jurisdictions, and implied by laws in others. Confidentiality in this context refers to the protection from disclosure of all the information, that is, what in discourse analytical terms is called "discursive data", whether spoken or written, relating to, submitted or presented during, or resulting from an arbitral proceeding, to outsiders who are not participating or involved in the arbitral proceedings. In this context, Article 25.4 of the UNCITRAL Arbitration Rules 1976 says:

Hearings shall be beld in camera unless the parties agree otherwise. The arbitration tribunal may require the retirement of any witness or witnesses during the testimony of other witnesses.

The implication is that, if the hearing is held in camera, and where evidence will invariably be private in nature, then all the documents presented during the hearing and also the documents resulting from the hearing, including the award itself, shall also be kept confidential. However, this is not viewed as an absolute duty of confidentiality in arbitral proceedings. Article 32.5 of the UNCITRAL Rules allows the award to be made public with the consent of both parties. This rule also suggests that, if the parties agree, then the whole proceeding may be open to the public, including the publication of award.

In a similar way, neither the New York Convention on the Recognition and Enforcement of Foreign Arbitral Awards 1958, nor the European Convention on International Commercial Arbitration 1961 envisages the obligation of absolute confidentiality. Moreover, when the award is filed in the court for enforcement then part of the award becomes public, thus undermining in effect any duty of confidentiality. In actual practice, courts in different jurisdictions have refrained from accepting an absolute duty of confidentiality. The perceptions of the arbitration community are also varied. Yves Fortier (1999), for instance, rightly observes that the principle that a duty of confidentiality exists, at least, in the absolute form in which it is generally understood by most parties, is more truism than truth. The basic questions ranging from the nature and scope of the principle, in law, to its utility, in practice, to its 
formulation as a rule of arbitral procedure, are highly contentious, he points out.

Similarly, Alexis Brown (2001) points out that a 'presumption of confidentiality, whether implied or explicit, exists between the parties to an international commercial arbitration'. 'However, there is a disconnect between that presumption and the frequent realities of disclosure and publicity imposed by courts, arbitrators, and sometimes even the parties themselves', he continues. Despite the English Court of Appeal's 1997 decision in Ali Shipping v Shipyard 'Trogir', which signalled a revived movement toward a judicially enforceable duty of confidentiality, he claims, the question of confidentiality in international arbitral proceedings is far from settled.

These observations indicate that the duty of confidentiality is implied rather than absolute and is subject to limitations and exceptions to be decided case by case. One of the exceptions to this duty of confidentiality has been well-established in Esso Australian Resources Ltd v The Honourable Sydney James Plowman, where the Australian court decided that confidentiality was not an essential attribute when there was a legitimate interest in obtaining information of public interest.

Sometimes, it is also argued that the disclosure of an arbitral award should be permissible if it helps to establish a cause of action in subsequent arbitration proceedings. In this context, Justice Colman J. writing in Hassneh case wrote at [247]-[248]:

[...] since the duty of confidence must be based on an implied term of the agreement to arbitrate, that term must have regard to the purposes for which awards may be expected to be used in the ordinary course of commerce and in the ordinary application of English arbitration law.

This case established an exception to the obligation of confidentiality. An award rendered in an earlier arbitration may be disclosed in subsequent litigation to prove the basis for the subsequent claim. Sir Bernard Rix (2006, p. 226) sums up a similar position in the English arbitration tradition as follows: 
The English rule is that arbitration proceedings are prima facie confidential, but there are exceptions: thus (i) the parties may consent to lift confidentiality; (ii) the arbitration proceedings may get into the courts; (iii) the interests of justice may require disclosure.

Although it is true that there is a large degree of variation in the perceptions about the general duty of confidentiality in international commercial arbitration, it is still very difficult to get access to the discourses of and in arbitration practice. Off-stage narratives of experience of arbitration practitioners are not very difficult to have access to, but their on-stage performance in the arbitration trial (GOFFMAN, 1959) is still largely inaccessible for any kind of research. However, there has been a degree of relaxation observed in the case of written discourses in and of arbitration, the prime example of which is the arbitration award, to which we shall turn to now.

\section{ARBITRATION AWARDS}

One of the important purposes of publishing awards is to educate potential stakeholders and also the providers of arbitration services. Referring to this issue, Sir Bernard Rix (2006, p. 227) points out:

The more that arbitration awards are final and supplant and avoid any visit to the courts, the more commercial parties have, it seems to me, a real and justifiable interest in being able to discover for themselves how arbitration tribunals in general and individual arbitrators or boards of arbitrators in particular, decide and perform. They should not be simply in the hands of their legal advisers, who give them anecdotal information. Moreover, the legal advisors themselves should be in a position where they can advise their clients on an informed basis about the principles applied by and performance of arbitrators.

There is also the matter of accommodating public interest in the review of arbitration proceedings, which can only be served by the 
introduction of some transparency and disclosure of information regarding such arbitral proceedings and awards. In view of this paper, then, there appears to be an established case for making some elements of the arbitral proceedings more transparent and free from the obligation to observe confidentiality. As one example, the UNCITRAL Notes on Organizing Arbitral Proceedings in note 32 encourages parties to include in a confidentiality agreement only those elements of the proceedings that are necessary for individual cases.

Note 32 - UNCITRAL Notes on Organizing Arbitral Proceedings - Possible content of a confidentiality Agreement.

An agreement on confidentiality might cover, for example, one or more of the following matters: the material or information that is to be kept confidential (e.g. pieces of evidence, written and oral arguments, the fact that the arbitration is taking place, identity of the arbitrators, content of the award); measures for maintaining confidentiality of such information and hearings; whether any special procedures should be employed for maintaining the confidentiality of information transmitted by electronic means (e.g. because communication equipment is shared by several users, or because electronic mail over public networks is considered not sufficiently protected against unauthorized access); circumstances in which confidential information may be disclosed in part or in whole (e.g. in the context of disclosures of information in the public domain, or if required by law or a regulatory body).

To sum up, we may say that arbitration in recent years has become relatively more transparent in that the rules from various regulatory organizations have become accessible to stakeholders, and at the same time noting that there has been an increasing number of voluntary disclosures that provide information about the way arbitration takes place. As Catherine Rogers and Richard Cadwallader (2006) point out:

Arbitral decision making in the past occurred in a virtual black box $[\ldots]$. At that time, international commercial arbitration was 
predominantly a compromise-oriented process [...]. Instead of formal, transparent rules, arbitrators crafted proceedings based on their culturally defined professional experiences and (their) sense of what was equitable and just. As a consequence of these conditions, parties had little ability to peek at the inner workings of the decisional machine. Even if they could, the number of skilled arbitrators and recognized institutions were few, so there was no basis for comparison shopping. High rates of voluntary compliance also ensured that national courts would not be able to glimpse inside the system during enforcement proceedings.

Today the situation is somewhat different. A series of reforms have made international commercial arbitration considerably more transparent, meaning that the rules that regulate decision-making are more readily available to interested parties, who in this instance are the users of the system. At the same time, a growing number of voluntary and involuntary disclosures provide increased information to the users, as well as to the general public, about numerous individual cases. While the disclosures generally are made for reasons other than to advance transparency, the information they provide inevitably illuminates the inner workings of the international commercial arbitration system. The parties can also impose a contractual obligation of non-disclosure for researchers before admitting them as observers in arbitral proceedings.

The following examples offer some instances of the relaxation of the absolute conditions of confidentiality. In Associated Electric and Gas Insurance Services Ltd v European Reinsurance Co of Zurich, the Privy Council decided that the essential nature of commercial arbitration was private proceedings and that unlike litigation in public courts information is not placed within reach of the public. As such, the implied restrictions on the use of documentation and materials obtained in arbitration proceedings will have a greater impact than similar materials in litigation. However, the Privy Council significantly decided that, where the issues of confidentiality touched on the award, there may not be the same degree of implied restriction of confidentiality. The reasoning given was that an award may later have to be referred to for accounting purposes or in legal proceedings and for the practical purpose of enforcing the rights conferred by the award itself. 
Another study by the advocates of publication of awards concluded that confidentiality was not one of the most valued aspects of international commercial arbitration and that less than 10 per cent of the participants that had been surveyed had indicated confidentiality as one of the important aspects of arbitration. The ICC International Court of Arbitration has started publishing important extracts from its awards, after they have been adequately sanitized by the removal of any identifying information, and which are then available for comment by academics, practitioners, and other experts.

The advantage of having a repository of awards can hardly be overlooked. The disclosure of such awards could be used as educational samples during the course of training of arbitrators. It could also lead to the development of the law and practice of arbitration and the encouragement of consistency by future arbitrators in reasoned international awards. These collections of awards can have persuasive value in allowing arbitrators to collectively share experiences and can be used as examples by potential parties and future arbitrators. This sharing of experiences and the greater transparency could then set the basis for allowing arbitrators, practitioners, and academics to understand, discuss, and provide constructive criticisms of awards. This in turn is likely to lead to greater assistance in improving arbitration itself as a workable and reliable dispute resolution system.

\section{ARGUMENTS AGAINST THE GENERAL (IMPLIED) DUTY OF CONFIDENTIALITY}

In arbitration practice the courts from time to time have established exceptions to the duty of confidentiality, some of which we have already been referred to. The intention of this paper is not to be comprehensive on this issue, but to establish some of the purposes whereby, and circumstances in which, the duty of confidentiality can be waived. In what follows, we briefly summarize the arguments against the need for an implied duty of confidentiality in all arbitral proceedings and awards.

First, a strict adherence to the confidentiality requirement of arbitral proceedings can produce inconsistent resolutions of disputes arising out of the same transaction. International business practices often 
give rise to a number of related disputes involving different parties. International commercial arbitrations can often involve common issues of law or fact. In order for arbitrators, judges, and other stakeholders to benefit from others' experiences, the proceedings and awards must be made transparent and accessible.

Secondly, availability of arbitral documents and awards may be useful for the purpose of training new or less experienced arbitrators. At the moment, the resources used for training purposes are based on impressionistic and anecdotal materials, many of which may be adequate in illustrating some of the general arbitral principles, but most of which display considerable variation in their applications to actual practice.

Thirdly, confidentiality is often undermined by challenges in the courts, especially in some jurisdictions. More recently, given that the number of awards that end up in the courts is on the increase, it may seem futile to safeguard the duty of confidentiality in all aspects of arbitral proceedings.

Fourthly, it has been found in several recent studies that, although the requirement of confidentiality is one of the important elements of international commercial arbitration, it is not the most important for corporate stakeholders. Flexibility in the arbitral procedures and the finality of awards remain the two most important factors in their preference for arbitration over litigation.

Fifthly, the confidentiality requirement acts as a significant obstacle to the development of arbitration as a true alternative to litigation, making it almost impossible to control the quality of service provided by the institution and the individual arbitrators. If a general duty of confidentiality is imposed or implied, then there is no way of evaluating or reviewing the quality of practice available to corporate stakeholders. If a corporation has to decide between litigation, arbitration, or mediation, it is almost impossible for it to decide in favour of arbitration, except on the advice of legal counsel. This constraint may become a significant negative factor in the development of arbitration as a preferred alternative in the long run. Discussing various kinds of exceptions, Trakman (2002, p. 1) points out: 
Exceptions to requirements of confidentiality are variously defined. Such exceptions arise by agreements between the parties, through party practice and trade usage, or on account of express or implied legal duties. Exceptions may also be warranted for public policy reasons. For example, confidentiality ought not to be used to disguise evidence of a crime. More controversial is the extent to which a court or arbitrator may waive confidentiality if it is being used as a pressure tactic, such as to force settlement or to extract some other advantage. Exceptions as between parties to an arbitration may be justified for various reasons. For example, a party may ask the other for an exemption from confidentiality in order to secure or perform a third party contract. Exemptions may also be requested by the participants who are not parties to an arbitration. For example, an international arbitration association may request an exemption in the interest of research, such as to compile information about cases submitted to them, the types of issues in dispute and the size of awards. (Emphasis added.)

There is an increasing number of developing and least developed countries that are in the process of establishing arbitration institutions and making their own rules of arbitration. In order for those newly established and establishing institutions to be more persuasive in attracting clients, it would be helpful if their awards were published so that corporate clients might obtain some evidence of quality so as to judge their arbitration practices. Having famous and experienced arbitrators on the list of arbitrators may not in itself be persuasive, especially as it is well known, and indeed likely, that most of these arbitrators will be otherwise engaged, and hence unlikely to be available to arbitrate in such newly established jurisdictions. Consequently, it is more than likely that a dispute will be arbitrated by local arbitrators, or by relatively less established arbitrators, a matter which raises, once again, the issue of arbitration quality.

Finally, the confidentiality requirement may act both ways, as a negative as well as a positive element for stakeholders. It is not impossible to imagine a situation where the parties demanding a reciprocal confidentiality obligation may lose beneficial publicity, especially if they get a favourable award. 


\section{ALTERNATIVES SOURCES OF DATA}

Public access and transparency tends to encourage quality control in the decision-making process, enhancing its legitimacy. Similarly, disclosure of information can enable parties and other stakeholders to make evidence-based and informed choices for arbitration as an alternative to litigation. Although it is possible to make a fine distinction between transparency and disclosure of information, in practice these constructs are not always easy to distinguish. Disclosure of information creates favourable conditions for the monitoring of decision-making in arbitral proceedings. Taken together they have great potential for monitoring decision-making, and, at the same time, protecting public interest and creating a body of jurisprudence in the system of arbitration as an effective alternative to litigation. The important question remains, however, "which elements of arbitration practice must necessarily be kept confidential, and which ones need to be more transparent"?

It is against this background of confidentiality requirements, and the challenges to them, and the clear advantages of greater transparency, for all the reasons we cite above, that this research study we outline may be of some practical significance. For this to eventuate, access to arbitration proceedings and procedures is clearly central. However, in the absence of any support from professional and institutional practitioners, we were forced to look for alternative sources of discoursal data from arbitration practice. In this respect, we discovered two potentially useful alternatives for the collection of data.

The first alternative was for the collection of substantial sections of arbitration awards, which we discovered could be collected from the court proceedings, when arbitration awards are challenged, especially from the courts of first instance, where substantial sections of awards are quoted verbatim. There are a number of advantages in getting sections of awards from these contexts: they are crucial sections of awards that become the focus of interpretation; they are quoted at crucial moments of interaction in the process of negotiation of justice in the court of law; they are all embedded in critical sites of engagement, that is, the challenge to awards; and they offer interesting contexts for comparison of awards and court judgments. It must be pointed out that awards are rarely published in full; they are sanitized and only certain sections are 
published. Although it is true that the ideal kind of data would be the complete, authentic, and original, but the alternative is perhaps not very problematic either.

The alternative to spoken data from arbitration trials is almost impossible to get. The alternatives are, some data from training videos, arbitration moots, practitioners accounts, reconstructions based on narratives of experience, views expressed in journal articles and practitioner magazines, etc., which are not excellent substitutes, but are nevertheless quite helpful in the reconstructions of arbitral processes.

\section{CONCLUSIONS}

In this article, I have made an attempt to highlight one of the major issues in the study and analysis of professional practice, that is, the non-accessibility of discoursal data. The illustration that I focused on comes from one of the international initiatives that I have been involved in, i.e., the interdiscursive colonisation of international commercial arbitration practice, which, by its very nature, is made non-accessible to outsiders. In the absence of accessibility of discoursal data from practice, though it is often possible to study professional genres (SWALES, 1990; BHATIA, 1993), it is almost impossible to study professional practice, which requires a critical genre analytical approach that crucially focuses on the way genres are used in actual practice to achieve professional objectives. It is a crucial distinction for our study, as one studies textual products, whereas the other studies textual action (see, for a detailed account of this distinction, Bhatia, 2008b, and 2010). I have also tried to make a claim, with some justification I hope, that the issue of privacy and confidentiality which makes discoursal data non-accessible for this kind of research, is not something which should be taken as a given or generally implied in all forms of arbitration practice. I have argued that instead of taking the duty of privacy and confidentiality as a 'given', it should be 'negotiable' in the initial phase of arbitral process as is the case with other procedural issue. It is not possible to negotiate such procedural issues in a court trial, which is highly institutionalized and regulated, but it is certainly possible to negotiate in an arbitral process, in which all procedures are negotiated across the disputing parties, and the arbitrators have enough control over such decisions. Unfortunately, 
however, it is not done in practice, not even for the sake of research of this kind, which can be beneficial for the development of the institution of arbitration and training of arbitrators, which should be one of the most important concerns today. Perhaps the professional community is too worried about protecting their own individual business interests, in that they are not seen as too 'soft' on privacy and confidentiality.

\section{REFERENCES}

BHATIA, V. K. Analysing genre - language use in professional settings. London: Longman, 1993.

. Genre-mixing and in professional communication: The case of 'private intentions' v. 'socially recognised purposes'. In: BRUTHIAUX, P. ; BOSWOOD, T.; BERTHA, B. (Eds.), Explorations in English for professional communication. City University of Hong Kong: Hong Kong, 1995. p. 1-19.

Worlds of written discourse: a genre-based view. London: Continuum International, 2004.

Genre analysis, ESP and professional practice. English for Specific Purposes, v. 27, p. 161-174, 2008a.

Towards critical genre analysis. In: BHATIA, V. K.; FLOWERDEW, J.; JONES, R. (Eds.). Advances in discourse studies. London: Routledge, 2008b.

. Interdiscursivity in professional communication. Discourse and Communication, v. 4, n. 1, p. 32-50, 2010.

BOJE, D.; OSWICK, C.; FORD, J. (Eds.). Language and organization: The doing of discourse. Academy of Management Review, v. 29, n. 4, p. 571-577, 2004.

BROWN, A.C. Presumption meets reality: an exploration of the confidentiality obligation in international commercial arbitration. American Uniform International Law Review, 969, 2001.

CANDLIN, C. N.; MALEY, Y. Intertextuality and interdiscursivity in the discourse of alternative dispute resolution. In: GUNNARSSON, B-L; LINNEL, P.; NORDBERG, B. (Eds.) The construction of professional discourse. London: Longman, 1997. p. 201-222. 
ROGERS, C. A.; CADWALLADER, R. C. Secrecy and transparency in dispute resolution: Transparency in international commercial arbitration. Kansas Law Review, v. 54, 1301, 2006.

FORTIER, Y. L. The occasionally unwarranted assumption of confidentiality. Arbitration International, v. 15, 131, 1999.

GEERTZ, C. Thick description: toward an interpretive theory of culture. In: The interpretation of cultures: selected essays. New York: Basic Books, 1973. p. 3-30.

GOFFMAN, E. The presentation of self in everyday life. New York: Doubleday, 1959.

GRANT, D.; KEENOY, T.; OSWICK, C. (Eds.). Organizational discourse: Key contributions and challenges. International Studies of Management and Organization, v. 31, n. 3, p. 5-24, 2001.

HARDY, C.; GRANT, D.; KEENOY, T.; OSWICK, C.; PHILLIPS, N. (Eds.) Organizational discourse. Organizational Studies, v. 25, n. 1, 2004.

KRISTEVA J. Word, dialogue and novel. In: KRISTEVA, J. (Ed.) Desire in language. Oxford: Blackwell, 1980. p. 64-91.

MARSHAK, R. J.; KEENOY, T.; OSWICK, C.; GRANT, D. From Outer words to Inner Worlds. The Journal of Applied Behavioral Science, v. 36, n. 2, p. 245-258, 2000.

NARIMAN, F. The spirit of arbitration, the Tenth Annual Goff Lecture. Arbitration International, v. 16, n. 3, 2000.

OSWICK, C.; GRANT, D. Organizational metaphors: ways of thinking or sources of emptiness. In: GLINKA, B.; HENSEL, P. (Eds.). The space report, special issue of Master of Business Administration. Warsaw: The Academy of Entrepreneurship and Management, 1997.

PHILLIPS, N.; Hardy, C. Discourse analysis: investigating processes of social construction. Thousand Oaks: Sage Publications, 2002.

RIX, B. Three addresses in St Petersburg Conference: International arbitration, yesterday, today and tomorrow (April, 2006). Arbitration, v. 72, 227, 2006.

SARANGI, S.; CANDLIN, C. N. Motivational relevancies: some methodological reflections on social theoretical and sociolinguistic practice. In: N. COUPLAND, N.; SARANGI, S.; CANDLIN, C. N. (Eds.).

Sociolinguistics and social theory. Harlow: Pearson Education, 2001. 
Making methodology matter, editorial. Journal of Applied

Linguistics, v. 1, n. 2, p. 101-107, 2004.

SCOLLON, R. Mediated discourse: the nexus of practice. London:

Routledge, 2001.

SWALES, J. M. Other floors other voices: a textography of a small university building. London: Lawrence Erlbaum, 1998.

TRAKMAN, L. E. Confidentiality in international commercial arbitration.

Arbitration International, v. 18, n. 1, 2002.

\section{CASES}

Ali Shipping Corp v Shipyard Trogir [1998] 1 Lloyd's Rep. 643.

Esso Australian Resources Ltd v The Honourable Sydney James Plowman [1995] 183. C.

L. R.

Hassneh Insurance Co of Israel v Stuart J. Mew [1993] 2 Lloyd's Rep. 243.

Recebido em 30/08/2010. Aprovado em 26/11/2010.

Título: Acessibilidade de dados discursivos em Análise Crítica de Gêneros: prática de arbitragem no comércio internacional

Autor: Vijay K. Bhatia

Resumo: A análise crítica de gênero, especialmente quando enfoca práticas profissionais específicas, depende de modo crucial da disponibilidade de dados discursivos da prática profissional sob investigação, o que nem sempre é fácil. Neste artigo abordo um exemplo típico desse tipo de dificuldade, enquanto enfoco uma iniciativa internacional em que estive envolvido nestes últimos anos, com a colaboração de mais de vinte equipes de pesquisa de um mesmo número de países. Ao nos debrucarmos sobre dados discursivos (narrativos, documentais e interacionais), é possivel enxergar as motivaçoes para processos e procedimentos interdiscursivos. Entretanto, o assim chamado dever de estrita confidencialidade, observado e praticado nas práticas de arbitragem internacional, torna difícil o acesso aos dados das práticas de arbitragem e, assim, de levar adiante uma pesquisa interdisciplinar crítica com base na noção de gênero. No presente artigo enfocarei algumas das questões importantes envolvidas no estudo da prática profissional e discutirei as implicações desse requisito de confidencialidade amplamente obedecido, bem como suas implicações para a pesquisa na e desenvolvimento da instituição de arbitragem. Também proponho alternativas para a coleta de dados da prática de arbitragem, de modo a tornar esse tipo de pesquisa possivel.

Palavras-chave: Análise crítica de gênero. Práticas profissionais. Práticas de arbitragem.

BHATIA - Accessibility of discoursal... 
Título: Acessibilidad de datos discursivos en análisis crítico de géneros: práctica de arbitraje en el comercio internacional

Autor: Vijay K. Bhatia

Resumen: El análisis crítico de género, especialmente cuando enfoca prácticas profesionales específicas, depende de modo crucial de la disponibilidad de datos discursivos de la práctica profesional bajo investigación, lo que ni siempre es fácil. En este artículo abordo un ejemplo típico de ese tipo de dificultad, mientras enfoco una iniciativa internacional en la que estuve envuelto en estos últimos varios años, con la colaboración de más de veinte equipos de investigación de un mismo número de países. Al inclinarnos sobre datos discursivos (narrativos, documentales e interacionales), es posible ver las motivaciones para procesos y procedimientos interdiscursivos. Al mismo tiempo, el asi llamado deber de estricta confidencialidad, observado y practicado en las prácticas de arbitraje internacional, vuelven difícil el acceso a los datos de las prácticas de arbitraje y, así, de llevar adelante una investigación interdisciplinar crítica con base en la noción de género. En el presente articulo enfocaré algunas de las cuestiones importantes involucradas en el estudio de la práctica profesional y discutiré las implicaciones de ese requerimiento de confidencialidad ampliamente obedecido, bien como sus implicancias para la pesquisa en el desarrollo de la institución de arbitraje. También propongo alternativas para la colecta de datos de la práctica de arbitraje, de modo a tornar ese tipo de investigación posible.

Palabras-clave: Análisis crítico de género. Prácticas profesionales. Prácticas de arbitraje. 